\title{
Argentina: recent dynamics in the software and IT services industry
}

\author{
Florencia Barletta, Mariano Pereira, Verónica Robert \\ and Gabriel Yoguel
}

ABSTRACT

This article examines the impact of organizational and absorptive capacities and networking on the performance of Argentine software and IT services firms, within an evolutionary theoretical framework. The models estimated show that innovation outcomes depend on quality management, the existence of research and development (R\&D) staff and on occupying intermediate positions in the network architecture. Firms' economic performance cannot be assessed using a single set of indicators: whereas productivity is explained by the qualifications of human resources and employment growth by R\&D personnel, export probability is associated with obtaining certifications, adopting agile methodologies and occupying intermediate positions in the network architecture. The heterogeneity of business models suggests that it is not possible to establish a single type of relationship between innovation and performance for all firms in the industry.

KEYWORDS

JEL CLASSIFICATION

AUTHORS
Industry, informatics, software, services trade, innovation, research and development, quality management, measurement, evaluation, Argentina

O14, O30, L86

Florencia Barletta is a lecturer and researcher at the Institute of Industry of the Universidad Nacional de General Sarmiento.mfbarletta@gmail.com

Mariano Pereira is a lecturer and researcher at the Institute of Industry of the Universidad Nacional de General Sarmiento. yomarianopereira@yahoo.com.ar

Verónica Robert is a lecturer and researcher at the National Council of Scientific and Technical Research (CONICET) and at the Institute of Industry of the Universidad Nacional de General Sarmiento. vrobert@gmail.com

Gabriel Yoguel is a lecturer and researcher at Institute of Industry of the Universidad Nacional de General Sarmiento and Coordinator of the Knowledge Economy Research Programme (PIEc). gyoguel@gmail.com

All four authors are engaged in work on the Knowledge Economy Research Programme (PIEc) www.ungs.edu.ar/piec 


\section{I}

\section{Introduction}

Since Argentina's currency devaluation of 2002, the software and IT services industry has been one of the fastest growing sectors in the economy. Between 2003 and 2010, jobs in the industry overall were up by an annual average of $17.8 \%$, sales by $17.6 \%$ and exports by $21.4 \%$ (OEDE, 2012; CESSI, 2012). These figures were well above the $3.8 \%, 8.3 \%$ and $13.0 \%$, respectively, posted by Argentina's manufacturing industry, ${ }^{1}$ and stood out at the regional level, as well. ${ }^{2}$ This performance appears to be attributable to the Argentine economy's enhanced competitiveness following the currency devaluation and to domestic market growth, as well as the spread of outsourcing and global software development, which boosted a large number of software and IT services

$\square$ This work further develops the final report of the project on absorption capacities and connectedness in local production and innovation systems financed by Carolina Foundation of Spain.

1 Notwithstanding strong growth in Argentina's software and IT services industry since the devaluation of 2002, the State made notable efforts in the preceding decades, in the context of the fluctuations of the Argentine economy since the 1970s (Aspiazu, Basualdo and Nochteff, 1986 and 1990; Babini, 2003). Around 1962, a group of engineering researchers built the first Argentine computer, named Census, which led to another two prototypes in that decade. By the mid-1960s Argentina had made great strides in informatics, in the Latin American context. In those early stages of the industry, in Argentina and elsewhere, software development was directly linked to hardware. In the early 1970s, IBM set up a plant producing printers and other peripherals. The crisis of import substitution industrialization and the opening of the economy in the 1976-1983 period hurt the development of the sector. After the debt crisis of 1982, policies between 1983 and 1991 centred on subsidies for the industry and the creation of a joint ArgentineBrazilian informatics research programme, which drew attention to the need for personnel highly skilled in software development. As a result, the Latin American School of Informatics (ESLAI) was created in 1986, only to be dismantled in 1991. During the market opening and deregulation phase (1991-2001) the idea prevailing was that technical progress gained from importing hardware and software would produce knowledge spillovers throughout the production structure. Before the 2002 devaluation, Argentina's software and IT services industry showed minimal domestic sales and exports, employment and productivity compared to the same industry in more developed countries and in India, Ireland and Israel (Arora and Gambardella, 2005; López and Ramos, 2007; OECD, 2002).

2 Employment in the software and IT services industry was twice as high in Argentina as in Uruguay in 2003, and five times as high in 2010 (CUTI, 2012; CESSI, 2012). From 14\% of Brazil's figure in 2003, the Argentine sector's employment went to $21.5 \%$ in 2010 (SOFTEX, 2012; RAIS, 2012; OEDE/MTSS, 2012). The ratio of exports to sales in 2010 $(19 \%)$ lay between the ratio for Brazil (5\%) and Uruguay (39\%), and was much lower than in India (76\%), Ireland (85\%) and Israel (73\%). firms. In addition, a set of public policies in place since 2004 has promoted quality certification, exports and innovation. These include the Fiduciary Fund for the Promotion of the Software Industry (FONSOFT) created under the Software Industry Promotion Act passed in 2004, infrastructure development and the promotion of informatics courses in tertiary education (Zuckerfeld and others, 2012). The rationale for these public policies was that building up firms' organizational capacities and innovation efforts would raise innovation performance, which would boost firms' production levels with benefits for employment, productivity and exports.

However, unlike in the manufacturing industry during this period, the rapid growth in employment, exports and even the export-to-sales ratio in software and IT services firms did not lead to higher levels of productivity. Consistently with evolutionary arguments on capacities and innovation, these outcomes appear to reflect the interrelations between internal and external knowledge sources (development of organizational and absorptive capacities and positioning in the network architecture), in a context of very different business models within the sector, which benefited innovative behaviour unequally (Yoguel and others, 2004). That is, the aggregate pattern of expanding sales, employment and exports masks sharp heterogeneities inasmuch as capacities, linkages, innovation and productive performance are not always related and the different measures of performance are only weakly associated.

At the same time, the importance of customized development, outsourcing and diversification strategies throws doubt - for services in general and software and IT services in particular - on the scope of the conventional definition of innovation performance, which is based on technology surveys and understood as the introduction of new or upgraded products and processes. This leads, in turn, to discussion of the importance of developing firms' capacities not only as a determinant of innovation outcomes, but even as the very definition of innovation in services.

In this framework, the following research questions arise: did the global, local and policy context affect all the firms in the sector equally, or does the aggregate performance hide sharp heterogeneities associated 
with different business models, uneven capacities and unequal connectedness? To what extent did this heterogeneity produce differentiated impacts on productivity, employment and exports? Lastly, to what extent are capacity-building and firms' network position and different commercial strategies related to innovation outcomes?

In this context, this article studies the characteristics of recent development in the software and IT services industry, using an evolutionary theoretical framework which emphasizes the role of absorptive and organizational capacities and the development of linkages on the basis of economic performance and innovation. A sample of 189 software and IT services firms in Argentina provides information for the period 2008-2010. This article offers a key contribution for examining the sector's recent development, since most previous works are either based on case studies or do not include post-devaluation performance (Chudnovsky, López and Melitsko, 2001).

Section II explains the conceptual structure of the article, combining evolutionary literature on innovation, the networking approach and literature on innovation in services (Gallouj and Weinstein, 1997; Djellal and Gallouj, 2001; Coombs and Miles, 2000; Gallouj and Savona, 2009), from which the working hypotheses are derived. Section III gives a brief overview of the empirical literature on innovation in the software and IT services industry. Section IV sets out the methodology used, the building of the indicators and the descriptive statistics. Section V discusses the main results of the models estimated, on which basis we may assess the extent to which innovation results and performance are explained by organizational and absorptive capacities, firms' position in the network architecture and their business model heterogeneity. Lastly, section VI sets forth the main conclusions.

\section{II}

\section{Theoretical framework and hypotheses}

The theoretical framework combines the evolutionary approach to the systemic nature of innovation (Nelson and Winter, 1982; Saviotti and Metcalfe, 1984; Silverberg, Dosi and Orsenigo, 1988; Dosi, 2000) with the social networking approach to knowledge generation and circulation (Powell, Koput and Smith-Doerr, 1996; Gulati, 1999; Barabási and Albert, 1999; Cowan and Jonard, 2004) and the literature on the nature of the innovation process in services (Gallouj and Weinstein, 1997; Djellal and Gallouj, 2001; Coombs and Miles, 2000; Drejer, 2004; Gallouj and Savona, 2009).

First, the evolutionary approach treats innovation as a systemic phenomenon which does not occur exclusively inside firms, but depends largely on their interaction with other agents in the system, such as other firms and innovation promotion agencies, consultants, technology centres, business chambers and universities. Both firms' capacities and the linkages they build in the effort to increase those capacities impact their possibilities of achieving innovations and of improving their productive and economic performance. Innovation is understood as the pairing of internal and external knowledge. Access to external knowledge depends on the linkages organizations create among themselves and the development of internal capacities. These capacities have to do with the concepts of absorptive capacity, defined as the ability to recognize, assimilate and apply external knowledge (Cohen and Levinthal, 1990), and organizational capacity, which refers to skills for codifying tacit knowledge through quality management and prevailing ways of organizing work with respect to the circulation of knowledge within the organization.

In this context, innovation is the outcome of a nonlinear dynamic in the learning process, and is driven by mutual support between capacities and connectivity. The local contexts in which firms act are crucial in order to understand their innovation behaviour. Contexts include institutional framework, policy context, competition processes, firms' position in the network of connections determined by their direct and indirect linkages, and the structural characteristics of the network. Insofar as innovation is the outcome of a systemic process, the evolutionary approach complements the networking approach.

As applied to evolutionary theory of innovation, the networking approach showed up the importance of indirect — not only direct- linkages in innovation 
processes. Evolutionary literature on innovation has long emphasized the importance of linkages with different agents and institutions in the innovation process (Freeman, 1991). In this framework, the literature has focused mainly on analysis of the impact of direct linkages between agents. However, the study of indirect linkages, i.e. firms' connectedness through their neighbours' linkages and the structural features of the global network, is relatively new. Research incorporating these dimensions of analysis - indirect linkages and network characteristics - has essentially used the social networks approach to describe the circulation and creation of knowledge within organizational networks (Boschma and ter Wal, 2006; Giuliani and Bell, 2005).

The literature on interorganizational and innovation networks has debated extensively the tension between the spread and the creation of knowledge (Cowan and Jonard, 2003; Watts, 2006). High local density makes a network good at spreading knowledge, but less so at introducing novelty, since all the agents in the industry have full information. By contrast, a completely random network constantly fuels novelty in a specific local environment, but is less helpful in spreading knowledge. An intermediate point is one that combines the characteristics of both regular high local density networks and random networks in which the paths between any two extremes are relatively short. These are small-world networks - those in which "cliques"3 of firms are linked by nodes acting as "bridges" (Watts, 2006). In this type of network, intermediate positions are associated with the introduction of innovations and with better performance than firms in central and peripheral positions. Several authors (Watts 1999; Hargadon, 2003; Cowan and Jonard 2003; Cowan and Jonard 2004; Verspagen and Duysters, 2004; Schilling and Phelps, 2004) stress that small-world networks stimulate capacity-building in firms and therefore improve innovation trajectories. In small-world network, very dense, clustered linkages can coexist with other, weaker linkages having more distant nodes within the network. Denser linkages promote trust and collaboration between firms, while relations with distant nodes bring new, non-redundant knowledge to the network core. Smallworld networks thus help to mobilize information and

3 The clique concept refers to a set of nodes which have all possible connections ("everyone connected with everyone"). Cliques can be of varying sizes depending on the number of nodes they comprise: a dyad and triad are the simplest forms of clique found in a network. innovation, routines, experiences and other resources that do not circulate within the firm's local environment, thereby boosting their learning processes.

However, the theoretical model discussed does not capture the specific innovation traits that may exist in services in general, and knowledge-intensive services in particular. The literature has shown that innovation in services is affected by certain specific aspects of their nature, such as nonmateriality, continuous reconfiguration of supply and the simultaneity of provision and consumption -involving major client interaction — which distinguish them from the manufacturing industry. At the same time, as services have became more important and it has thus become necessary to be able to compare innovation processes in services with those in industry, an interesting theoretical and methodological discussion has arisen on how to address issues of innovation in services. This discussion has focused on three perspectives: (i) an assimilation approach (ii) a demarcation approach, and (iii) a synthesis approach.

The assimilation approach was supported by authors who have argued that differences in innovation activity were greater within sectors than between industry and services each taken as a whole (Hughes and Wood, 2000; Sirilli and Evangelista, 1998). On this basis, innovation processes would require a similar theoretical and methodological treatment in both services and industry.

In opposition to the assimilation argument, several authors (Gallouj and Weinstein, 1997; Djellal and Gallouj, 1999 and 2001; Coombs and Miles, 2000) have developed a demarcation approach, which attributes characteristics to innovation in services which are not applicable to manufacturing. These authors identified several types of innovation found in services which could not, in principle, be applied to manufacturing activities. For example, innovations arising from interactions with clients or the codification of tacit knowledge generated during these interactions. So, for example, customized developments could lead to product innovations almost constantly, without entailing radical changes or even increasing firms' capabilities and routines. This position was questioned by Drejer (2004), who argued that the demarcation approach attributes particularities to services which are in fact present in manufacturing, including : (i) the importance of networks and external knowledge sources in innovation (De Bresson and Amesse, 1991), (ii) the centrality of the interactive, non-linear model of innovation (Landau and Rosenberg, 1986), and (iii) the importance of tacit knowledge codification. 
In response to these critiques, a synthesis position has emerged which basically recognizes services attributes in the provision of manufactured products, and vice versa. This reflects the Lancastrian view of the nature of products and services, which was reprised by Saviotti and Metcalfe (1984) and by Gallouj and Savona (2009). In this view, innovation occurs because of changes in: (i) characteristics of the service in terms of the value attributed to it by the end user, (ii) material and nonmaterial technical characteristics of the product, (iii) competence sets (capabilities) of suppliers and end users. Here, product innovations are not merely about adjusting to demand changes, but entail shifts in the competence sets of suppliers and users, and changes in the perceived characteristics (material and nonmaterial) of the service arising from that demand.

In light of the literature review, our arguments are based on the following premises: (i) innovation processes in software and IT services firms depend on learning derived from feedback between capabilities and linkages all through the service life cycle, and (ii) these processes occur at different levels of absorptive and organizational capacities which affect innovation outcomes in a differentiated manner.

From these premises the following hypotheses arise:

\section{Hypothesis 1}

Innovation outcomes in Argentine software and IT services firms depend on the development of absorptive and organizational capacities.

Interactions between firms and institutions form the architecture of connections that supports the circulation of information and knowledge. In particular, firms in intermediate network positions may be expected to be more dynamic innovators, since they draw upon knowledge and capacities from both firms at the network core and those on the periphery. This last point leads to hypothesis 2 .

\section{Hypothesis 2}

Innovation outcomes in Argentine software and IT services firms depend on the position they occupy in the network architecture. In particular, intermediate positions are associated with greater likelihood of obtaining positive innovation outcomes.

The third hypothesis aims to capture certain characteristics of the production processes discussed in the literature on innovation in services, such as nonmateriality or innovation linked to solving specific problems raised by clients. These characteristics show up in several of the business models of Argentine software and IT services firms, and are determined by the importance of supplier-client relations, the standardization of the service and the degree of diversification of the services firms offer.

\section{Hypothesis 3}

Innovation outcomes in Argentine software and IT services firms are determined by micro-heterogeneity within the sector, as manifested in their different business models. Firms whose main business lines are customized developments and own-brand products may be expected to achieve better innovation outcomes.

Lastly, on the basis of the theoretical approaches discussed, we may identify various determinants of innovation, in general, and in services, in particular. However, it remains to be established how these determinants (absorptive and organizational capacities, firms' network position and business models) relate to the recent growth in the sector in terms of employment, productivity and exports.

\section{Hypothesis 4}

The performance of Argentine software and IT services firms in terms of productivity, employment growth and exports depends on: (i) the level of development of absorptive and organizational capacities, (ii) the firms' position within the network architecture, and (iii) the micro-heterogeneity evident in the different business models.

These hypotheses are expected to bring us closer to the research questions posed in introduction, referring to determinants of innovation and the sector's recent performance. 


\section{III}

\section{Empirical background on estimating innovation in software and IT services firms}

A number of attempts have been made in the past few years to conceptualize and measure the determinants of innovation in software and IT services firms (Romijn and Albaladejo, 2002; Segelod and Jordan, 2002; Boschma and Weterings, 2005; Grimaldi and Torrisi, 2001; Parthasarathy and Aoyama, 2006; Corrocher, Cusmano and Morrison, 2009; Cusumano and Yoffie, 1999; Cusumano, 2012, among others). Generally speaking, these works have explored the links between capacity-building, linkages and innovation using both panels of microdata and case studies. Studies have identified some of the key characteristics of the industry that make the respective learning processes so very specific. These include: (i) the high ratio of R\&D spending to sales, (ii) the large proportion of highly skilled workers in relation to total staff, (iii) the importance of links with universities and technology institutes, and with suppliers; and (iv) the high frequency of collaborative work between clients and suppliers in the framework of customized developments, outsourcing and communities of practice. The ways in which these characteristics affect innovation outcomes is not always evident, and suggest that the very definition of innovation, as well as how it is measured, needs to be rethought. Of these works, three concern us here as central to the current research, because they address the role of interactions and client relations in producing innovation, and examine the determinants of firms' performance.

First, Segelod and Jordan (2002) analyse the effect of the supplier-client relationship in introducing innovation in 92 software projects, mainly in Europe. These authors remark on the importance of links with clients in learning processes vis-à-vis links with technology centres and universities. They also show that the number of links firms have is positively correlated with the innovation level of the project and with the possibility of opening new markets and therefore increasing the firm's competitiveness. From a theoretical and conceptual point of view, Segelod and Jordan emphasize the importance of user-driven innovation in developing software and gaining access to new markets.

As these authors explain it, the clients of software and IT services firms have little clarity at the start of the development process about the problem they wish the software to solve, or indeed of the technological and organizational possibilities that it can offer once developed. The developers have the technical knowledge, but are unfamiliar with the area of application of the software. As a result, it takes many meetings between clients and providers of software and IT solutions to define the requirements of the software, because they have to narrow the knowledge gap and translate information in both directions. These interactions are not confined to the design stage, however, since technical incompatibilities can arise as the project progresses which require the design to be reviewed. So, projects start with unclear parameters which become clearer over time, but are subject to review throughout the development process, and this make the process inherently collaborative. Accordingly, implementing a software project is more akin to an R\&D project than to developing a tangible product. As described by Gallouj and Savona (2009), feedback to and from the client is key to the requirement definition, design and development stages.

Second, Romijn and Albaladejo (2002) study the determinants of innovation performance in small electronics and software firms in the United Kingdom on the basis of internal and external knowledge sources. Internal sources include: (i) the educational level and experience of owners and managers, (ii) the professional qualifications of the labour force, and (iii) technology effort in the form of formal and informal $R \& D$, formal and informal training and investment in technology licences. External sources include: (i) intensity of networking with different agents and institutions, (ii) geographical proximity advantages associated with networking, and (iii) institutional support. These authors focus on product innovation as a measure of innovation performance. They propose three indicators: new products, number of patents and an innovation index - constructed on the basis of qualitative information - that captures the scope and significance of the firms' innovation outcomes. Their findings show that, among the internal sources, owners' previous experience and the proportion of engineers to total staff have a positive effect on firms' innovation performance. They also stress that having specialized knowledge and experience in science and engineering 
is a precondition for achieving innovation outcomes in high-tech firms. However, neither networking intensity nor geographical proximity contributed to innovation performance. Only linkages with R\&D institutions and with suppliers had a positive effect.

Lastly, Boschma and Weterings (2005) analyse 265 software and IT services firms in the Netherlands and find that firms' productivity, spin-off business opportunities and capacities are greater in ICT-intensive geographical areas. As a dependent variable these authors use innovation productivity, defined as the ratio of sales of new products developed by the firm to the number of staff employed in $R \& D$. This indicator is treated as a proxy for efficiency of routines and competences in the firm. The authors show that developing radically new products or services has a positive effect on innovation productivity. They also find that client and supplier involvement in designing the product/service and the firms' and the owners' previous experience had no effect on innovation productivity. The findings also show that firms with the least difficulties in securing clients have greater techno-organizational capacities. Lastly, they find three combined effects: (i) having previous experience in the software industry impacts positively on the link between development of a radical innovation and high innovation productivity; (ii) firms experiencing problems in capturing clients need to develop a more radically innovative product, which lowers productivity, and (iii) firms experiencing problems in securing new staff have higher innovation productivity when they are located in ICT-specialized regions.

Finally, the most significant previous work on software and IT services firms in Argentina was carried out in the last year of the convertibility scheme with a sample of 89 firms and was descriptive in nature (Chudnovsky, López and Melitsko, 2001). That work found that, although most of the firms had launched new products onto the market, the Argentine ones —especially those working in products rather than services- were the most innovationdynamic. The authors note, however, that these findings must be seen in context, since software development is per se an innovative activity, which points up the need to develop specific innovation indicators for the industry.

\section{IV}

\section{Methodology, construction of indicators and descriptive statistics}

The database used consists of 189 software and IT services firms interviewed in 2011.4 On average, they employ just under 60 staff, have annual sales of around US\$ 1.8 million and are active in the export market. These are mainly Argentine-owned firms, mostly established in

\footnotetext{
4 The sample design was based on a previous work of universe characterization conducted jointly with the Employment and Business Dynamics Observatory of the Ministry of Labour, Employment and Social Security. The sample took into account two variables: firm size and the impact of public subsidies awarded by the Ministry of production through the Software Industry Promotion Act, and by the Ministry of Science, Technology and Production Innovation through the Argentine Technological Fund (FONTAR) and the Software Industry Promotion Fiduciary Fund (FONSOFT). In 2010, there were around 1,600 firms with five or more workers in the sector, employing almost 57,000 people. Firms with fewer than five workers showed a low rate of continuity in the market, and so were excluded from the analysis of the universe and from the sample design. The firms benefiting from public schemes represented $22 \%$ of the universe of firms with five or more employees.
}

1990s. Most are located in the City of Buenos Aires and in Greater Buenos Aires (74\%) with the rest distributed in the provinces of Córdoba (21\%) and Santa Fe (5\%). Between 2008 and 2010 average staffing numbers grew by $20 \%$, well above the average for the economy at large (1\%).

A set of indicators was constructed to estimate firms' internal capacities. The indicators reflected two dimensions: absorptive capacities and organizational capacities. Absorptive capacity was estimated on the basis of two indicators. The first captured the level of education of workers across three ordinal categories: firms with a below-average proportion of university graduates $^{5}$ and no postgraduates (29\%); firms with an

\footnotetext{
5 The average of university graduates $(40 \%)$ is significantly higher than in the manufacturing industry (13\%); see the National Survey on Technological Innovation (ENIT) of the National Institute of Statistics and Censuses (INDEC), 2005.
} 
above-average proportion of university graduates and no postgraduates (26\%); and firms with more postgraduates than university graduates on the total staff $(45 \%)$. The second indicator reflects the availability and degree of formality of the firm's R\&D staff, across four categories: no R\&D staff (11\%), occasional informal staff (32\%), regular informal staff (28\%) and formal staff (29\%). Organizational capacities are estimated on the basis of: (i) an additive variable to capture firms' quality management ${ }^{6}$ efforts, with three possible values: one for firms which made up to 1 effort ( $25 \%$ of firms), two for firms which made between 2 and 3 efforts (37\%), and three for firms which made between 4 and 5 efforts, (ii) a variable for the quantity of quality certifications, including ISO 9000 standards, the capacity maturity model (CMM), TickIT ${ }^{7}$ and the Service Level Agreement (SLA). This variable takes three possible values: one for firms with no quality certification (39\%), two for firms with one certification $(43 \%)$ and three for firms with two or more certifications (18\%). Finally, (iii) a variable for the use of agile methodologies, ${ }^{8}$ which takes three values depending on whether firms never use these methodologies $(18 \%)$, use them sometimes $(44 \%)$ or always use them (38\%). Table 1 shows the matrix of correlations between indicators of internal capacities, which allows us to identify a number of statistically significant relationships. The presence and formality of R\&D staff is positively correlated with quality management. Workers' qualifications level, meanwhile, was positively correlated with quality certification.

The structural variables considered were firm size, estimated by the number of employees, and geographical location, age and access to promotion instruments. ${ }^{9}$ The relations between the capacities indicators and structural variables are shown in annex A. The significant results from the contingency tables include the following

6 Five alternatives were considered for quality management: traceability, internal audits, risk management, availability of staff specifically for quality management and a formally established department for quality management.

7 A quality-management certification programme for software development, supported primarily by the United Kingdom and Swedish software industries.

8 Agile methodologies are a new way of organizing work in the software and IT services industry based on iterative and incremental development, where requirements and solutions evolve through continuous collaboration with clients and different functional teams. This method is particularly suited to outsourcing and customized development, since it aids oversight of progress throughout the development life cycle.

9 Those firms are those participating in the Software Act and receiving assistance from FONTAR or FONSOFT under the Ministry of Science, Technology and Production Innovation. correlations: (i) all the capacities indicators correlate with firm size; (ii) firm age correlates positively only with the quality indicator, which means that older firms are overrepresented among those making the greatest quality efforts; (iii) access to subsidies shows a positive correlation with the indicators for quality management and certification, given that in general promotion schemes support this type of activity, (iv) lastly, there is no link between the capacities indicators and firms' geographical location.

In order to evaluate firms' connectedness we have built a knowledge network of firms and innovation promotion agencies. The network included the linkages that firms maintain with other firms and institutions — such as universities, technological centres and consultants - involved in R\&D, quality and technical assistance (see annex B). Connectedness level was estimated on the basis of each firm's coreness, ${ }^{10} \mathrm{a}$ measure of centrality indicating proximity to the nucleus in a centre-periphery structure. This indicator is then used to establish a hierarchy. ${ }^{11}$ Peripheral firms thus receive a low coreness coefficient, while those closer to the centre are attributed a higher rating, irrespective of the number of linkages they have. Table 2 shows that there is a positive correlation between size and coreness and that firms located in Buenos Aires and Córdoba have greater coreness than those in Santa Fe. Conversely, there are no significant differences in coreness by age and subsidies received.

Firms were also asked about their innovation outcomes in the period 2008-2010, from a range of six alternatives: (i) new products; (ii) new services; (iii) significant product upgrades; (iv) new or significantly upgraded processes; (v) new marketing channels, and (vi) organizational changes. These alternatives were used to build an indicator with three possible values: 1

10 Closeness of each node to the set of densely interconnected nodes in the network. Coreness was calculated using the nucleus/periphery algorithm in the continuous version of the UCINET software (Borgatti, Everett and Freeman, 2002). The algorithm is as follows:

$$
\rho=\sum_{i, j} \alpha_{i, j} \delta_{i, j} \text { where } \delta_{i, j}=1 \text { if at the nucleus and } 0 \text { if not }
$$

We chose to use coreness, rather than other measures of centrality, such as degree, betweenness and closeness, because coreness allows us to pinpoint the complementarity between density and structural holes. Greater density of direct linkages may not benefit firms, because it does not necessarily incorporate new information, unless the links can connect nodes that would otherwise be isolated.

11 This goes further than the estimates conducted by Romijn and Albaladejo (2002) and Segelod and Jordan (2002), which examine connectedness from an egocentric perspective similar to a degree indicator in social networks. 
Matrix of correlations between capacities indicators

(Coefficients of correlation)

\begin{tabular}{|c|c|c|c|c|c|c|}
\hline & & \multicolumn{2}{|c|}{ Absorptive capacities } & \multicolumn{3}{|c|}{ Organizational capacities } \\
\hline & & R\&D staff & $\begin{array}{c}\text { Worker } \\
\text { qualifications }\end{array}$ & $\begin{array}{c}\text { Agile } \\
\text { methodologies }\end{array}$ & Quality & Certification \\
\hline \multirow{2}{*}{$\begin{array}{l}\text { Absorptive } \\
\text { capacities }\end{array}$} & $\mathrm{R} \& \mathrm{D}$ staff & 1 & & & & \\
\hline & Worker qualifications & $0.2005^{*}$ & 1 & & & \\
\hline \multirow{3}{*}{$\begin{array}{l}\text { Organizational } \\
\text { capacities }\end{array}$} & Agile methodologies & 0.1132 & 0.0992 & 1 & & \\
\hline & Quality & $0.3152 *$ & $0.2179 *$ & 0.1055 & 1 & \\
\hline & Certification & 0.0976 & $0.1823 *$ & 0.1041 & $0.4943^{*}$ & 1 \\
\hline
\end{tabular}

Source: prepared by the authors on the basis of a survey conducted in the framework of the project financed by Carolina Foundation.

*Significant at $10 \%$.

Note: coefficients not marked with an asterisk $(*)$ are not statistically significant.

TABLE 2

Relation between coreness and structural variables

\begin{tabular}{lc|lc|lc|lc}
\hline Size & Coreness & Age & Coreness & Location & Coreness & Subsidy & Coreness \\
\hline Up to 10 employees & 0.004 & Up to 1990 & 0.016 & Buenos Aires & 0.016 & No & 0.015 \\
11 to 50 employees & 0.016 & $1991-2001$ & 0.020 & Córdoba & 0.014 & Yes & 0.016 \\
51 or more employees & 0.028 & 2002 - 2005 & 0.009 & Santa Fe & 0.004 & & \\
& & 2006 or later & 0.014 & & & & \\
\hline
\end{tabular}

Source: prepared by the authors on the basis of a survey conducted in the framework of a project financed by the Carolina Foundation.

Note: Coreness $=$ coefficient measuring network centrality.

for firms achieving up to one innovation, ${ }^{12} 2$ for firms achieving between 2 and 4 innovations and 3 for firms with 5 or 6 innovation outcomes. Most of the firms $(58 \%)$ fell into the second group, with the first group comprising $24 \%$ of firms, and the third, $19 \%$.

Three indicators were constructed to evaluate firms' performance: external-market participation in 2010, variation in employment between 2008 and 2010 and labour productivity in 2010. "External-market participation" was estimated using a binary variable indicating whether they exported in 2010 or not. "Variation in employment" between 2008 and 2010 considered four categories: (i) firms in which employment decreased (19\%); (ii) firms in which employment held steady (19\%); (iii) firms in which employment rose by up to

12 Given that most firms $(90 \%)$ achieved innovation outcomes, the control group comprised those who achieved one or none.
45\% (33\%), and (iv) firms in which employment rose by over $45 \%$ during the period $(29 \%)$. This indicator was positively correlated with firm size, signalling that a concentration process was under way during the period.

"Labour productivity" was estimated on the basis of sales per employee in 2010. This continuous variable was codified in four categories based on quartiles of the distribution of sales per employee. It correlated positively with firm age.

The industry's micro-heterogeneity is reflected in the different business models adopted by firms: (i) customized development; (ii) own-brand developments and services; (iii) outsourcing; (iv) services for third-party developments, and (v) diversified models. Looking at these alongside the structural variables (see table 3 ) shows that among firms that received subsidies, those producing customized developments or applying more diversified business models stood out. Firms developing their own brand and providing related services predominated among those with between 11 and 50 employees, while those 
producing customized developments stood out among firms with over 50 employees. With regard to age, firms established between 1991 and 2001 tend to be more diversified, while newer firms work in outsourcing or provide services for third-party developments. Lastly, with regard to geographical location, firms in Buenos Aires follow a more diversified business model, those in Córdoba are geared mainly towards customized developments and those in Santa Fe mostly develop own brand products and services.
Lastly, we analyse the relation between capacities and the various business models (see table 4). The group of firms making customized products stand out for having formal R\&D staff, employees with postgraduate qualifications and the largest number of quality efforts and certifications. This reflects the fact that firms dealing with specific client demands have a higher capacities threshold. The business model geared towards outsourcing stands out for quality certifications and absence of R\&D staff.

Relation between business models and structural variables (Percentages)

\begin{tabular}{|c|c|c|c|c|c|c|}
\hline & \multicolumn{6}{|c|}{ Classification of business models } \\
\hline & $\begin{array}{l}\text { Customized } \\
\text { products }\end{array}$ & $\begin{array}{l}\text { Own products } \\
\text { and services }\end{array}$ & Outsourcing & $\begin{array}{c}\text { Services for } \\
\text { third-party } \\
\text { products }\end{array}$ & Diversified & Total \\
\hline \multicolumn{7}{|l|}{ Subsidy: } \\
\hline- no & 26.3 & 30.5 & 38.5 & 66.7 & 25.0 & 34.9 \\
\hline - yes & 73.7 & 69.5 & 61.5 & 33.3 & 75.0 & 65.1 \\
\hline Total & 100.0 & 100.0 & 100.0 & 100.0 & 100.0 & 100.0 \\
\hline \multicolumn{7}{|l|}{ Size: } \\
\hline - up to 10 employees & 15.8 & 27.1 & 40.7 & 33.3 & 38.9 & 29.9 \\
\hline - 11 to 50 employees & 47.4 & 55.9 & 37.1 & 37.1 & 41.7 & 46.0 \\
\hline - 51 or more employees & 36.8 & 17.0 & 22.2 & 29.6 & 19.4 & 24.1 \\
\hline Total & 100.0 & 100.0 & 100.0 & 100.0 & 100.0 & 100.0 \\
\hline \multicolumn{7}{|l|}{ Age (year established): } \\
\hline - up to 1990 & 10.5 & 16.9 & 7.5 & 3.7 & 8.3 & 10.7 \\
\hline$-1991-2001$ & 42.1 & 44.1 & 29.6 & 44.5 & 47.2 & 42.2 \\
\hline$-2002-2005$ & 23.7 & 23.7 & 29.6 & 37.0 & 27.8 & 27.3 \\
\hline - 2006 onwards & 23.7 & 15.3 & 33.3 & 14.8 & 16.7 & 19.8 \\
\hline Total & 100.0 & 100.0 & 100.0 & 100.0 & 100.0 & 100.0 \\
\hline \multicolumn{7}{|l|}{ Province } \\
\hline Buenos Aires & 60.5 & 74.6 & 74.1 & 88.9 & 75.0 & 73.8 \\
\hline Córdoba & 34.2 & 16.9 & 22.2 & 11.1 & 22.2 & 21.4 \\
\hline Santa $\mathrm{Fe}$ & 5.3 & 8.5 & 3.7 & 0.0 & 2.8 & 4.8 \\
\hline Total & 100.0 & 100.0 & 100.0 & 100.0 & 100.0 & 100.0 \\
\hline
\end{tabular}

Source: prepared by the authors on the basis of a survey conducted in the framework of a project financed by the Carolina Foundation. 
Relation between business models and capacities indicators

(Percentages)

\begin{tabular}{|c|c|c|c|c|c|c|}
\hline & \multicolumn{6}{|c|}{ Classification of business models } \\
\hline & $\begin{array}{l}\text { Customized } \\
\text { products }\end{array}$ & $\begin{array}{l}\text { Own products } \\
\text { and services }\end{array}$ & Outsourcing & $\begin{array}{c}\text { Services for } \\
\text { third-party } \\
\text { products }\end{array}$ & Diversified & $\begin{array}{l}\text { Customized } \\
\text { products }\end{array}$ \\
\hline \multicolumn{7}{|l|}{ R\&D staff: } \\
\hline - none & 0.1 & 1.7 & 37.1 & 14.8 & 13.9 & 10.8 \\
\hline - occasional informal & 36.8 & 31.0 & 33.3 & 33.4 & 30.6 & 32.8 \\
\hline - regular informal & 18.4 & 34.5 & 22.2 & 25.9 & 30.5 & 27.4 \\
\hline - formal & 44.7 & 32.8 & 7.4 & 25.9 & 25.0 & 29.0 \\
\hline Total & 100.0 & 100.0 & 100.0 & 100.0 & 100.0 & 100.0 \\
\hline \multicolumn{7}{|l|}{ Absorptive capacities: } \\
\hline - low & 28.9 & 33.9 & 23.1 & 19.2 & 33.3 & 29.1 \\
\hline - high & 52.6 & 41.1 & 42.3 & 57.7 & 38.9 & 45.6 \\
\hline Total & 100.0 & 100.0 & 100.0 & 100.0 & 100.0 & 100.0 \\
\hline \multicolumn{7}{|l|}{ Quality efforts: } \\
\hline - up to 1 effort & 21.1 & 24.1 & 16.7 & 37.1 & 27.8 & 25.1 \\
\hline - 2 to 3 efforts & 26.3 & 31.1 & 45.8 & 44.4 & 44.4 & 36.6 \\
\hline-4 or 5 efforts & 52.6 & 44.8 & 37.5 & 18.5 & 27.8 & 38.3 \\
\hline Total & 100.0 & 100.0 & 100.0 & 100.0 & 100.0 & 100.0 \\
\hline \multicolumn{7}{|l|}{ Certifications: } \\
\hline - none & 34.2 & 39.6 & 29.2 & 42.3 & 47.2 & 39.0 \\
\hline - one certification & 42.1 & 48.3 & 45.8 & 42.3 & 33.3 & 42.9 \\
\hline - two or more certifications & 23.7 & 12.1 & 25.0 & 15.4 & 19.5 & 18.1 \\
\hline Total & 100.0 & 100.0 & 100.0 & 100.0 & 100.0 & 100.0 \\
\hline
\end{tabular}

Source: prepared by the authors on the basis of a survey conducted in the framework of a project financed by the Carolina Foundation.

R\&D: research and development.

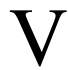

\section{Main findings of the models estimated}

This section presents a set of econometric models estimated to test the effect of building organizational and absorptive capacities, firms' network location and their business models on innovation behaviour and performance. The model proposed is as follows:

$$
\begin{aligned}
& Y_{i}=f(\text { absorption_cap } ; \text {; technology_cap } ; \text {; } \\
& \text { organizational_cap }_{i} ; \text { business_model }_{i} \text {; } \\
& n w k \_ \text {position }_{i} ; \text { control_vbles }_{i} ; \text { error_term }_{i} \text { ) }
\end{aligned}
$$

Four models were estimated on the basis of this equation. As the dependent variable was a discrete ordinal one (innovation, labour productivity and variation in employment), we have used a probabilistic model for ordered data. Firms' external-market participation was estimated on the basis of a probabilistic model. The independent variables used included: (i) capacities indicators (absorption_cap, tecnolology_cap and organizational_cap in the equation); (ii) each firm's network coreness and coreness squared (nwk_position) to take into account the possibility of a quadratic relation between this indicator, innovation and performance measurements, and (iii) the business model (business_ model), using four dummy variables, with the diversified 
business model as the base category. Lastly, availability of subsidies and firm size, age and location were included as control variables (control_vbles). The first model estimated the determinants of the quantity of innovations produced by firms. Partially confirming the first hypothesis presented in the theoretical framework, presence and degree of formality of R\&D staff were significant, showing the importance of absorptive capacities in producing innovations. ${ }^{13}$ Among organizational capacities, quality management showed up as significant. Consistently with hypothesis 2, the firm's network position has a positive impact on the number of innovations. In particular, both coreness and coreness squared are statistically significant, with a positive sign in the first case and a negative sign in the second. This result indicates that as firms' network coreness increases, the odds rise of them achieving a larger number of innovation outcomes, but after a certain threshold this probability begins to recede. This suggests that firms in intermediate network positions draw upon the knowledge and capacities both of more peripheral firms, and of those at the core. In terms of hypothesis 3 , the indicator which captures the different classifications of business model indicates that firms providing services for third-party products or geared towards outsourcing achieve fewer innovation outcomes on average than those with a diversified business strategy. These results do not corroborate the hypothesis proposed, because customization and own-brand products and services have no particular effect on innovation outcomes as compared with the diversified strategy.

The second model analyses the determinants of firms' productivity. In this case, only absorptive capacity, estimated on the basis of staff qualifications, had a positive impact. That is, the firm's productivity increased as the proportion of professionally qualified staff rose above the average for the industry, but it climbed even more for firms which - regardless of the proportion of university graduates in the total staff- had professionals with postgraduate qualifications on their staff. Lastly, of the control variables only firm age was significant, inasmuch as the older firms were the more productive.

Notably, none of the other variables used to estimate capacities, connectedness and business models were significant in explaining productivity. This may be because many firms have to expand their staff before allocating workers to specific projects: given the significant limitations imposed in this industry by the quantity and quality of available human resources, firms are forced

13 Romijn and Albaladejo (2002) produced similar findings. to engage in major internal training efforts in order to prepare the existing human resources. But it is also partly because there are both low- and high-capacity firms within the low-productivity group, making it impossible to establish significant relations in the model. This result also reflects the nature of competition in the sector, where the current high growth rate makes it possible to sustain low productivity levels in general, regardless of firms' capacities and future prospects. In Schumpeterian creative destruction terms, it may be said that the industry is at the stage of generating variety more than resolving it through selection.

The third model addresses determinants of employment variation. The results in this case indicate that of the independent variables proposed, only absorptive capacity, estimated on the basis of the availability and degree of formality of R\&D staff, is significant. That is, variation in employment rises as $R \& D$ staff increase, from firms which have no $R \& D$ staff, through those which have informal staff to those that have formal R\&D departments. In this case, neither business models nor the firm's network position are significant in explaining employment variation.

Of the control variables, firm size is positively associated with increased employment. This suggests that employment rose most in larger firms, which is in keeping with the trend towards higher concentration in the software and IT services industry observed in recent years (OEDE/MTSS, 2012). There was also a positive and significant link between firm age and employment variation, indicating that newer firms are more likely to increase employee numbers.

The fourth model shows that the probability of participating in external markets is correlated positively with network coreness and negatively with coreness squared. The reading of these results is similar to our earlier reading, insofar as firms located in intermediate positions in the network architecture are more likely to export. In turn, only organizational capacities are linked with export probability, with possession of certifications and the use of agile methodologies having a prominent effect. This may be because firms need to meet international standards in order to enter export markets, and because agile methodologies are important in fulfilling the oversight and monitoring requirements of developments for those markets. The results also show that, unlike in much of the manufacturing industry, the prevailing type of external-market participation does not necessarily need highly developed internal capacities.

Lastly, in terms of the role played by business model micro-heterogeneity, firms providing services 
for their own developments showed a greater export propensity than those with a diversified strategy. Of the control variables, firm size was not significant, which may be because —unlike in manufacturingexports of software and IT services do not involve high logistical costs.
In sum, the analysis of the last three models suggests that hypothesis 4 is partly borne out, with results differing depending on the measure of performance used. Consequently, the heterogeneity of the results points to the impossibility of explaining each firm's performance on the basis of a homogenous set of indicators.

Results of the models

\begin{tabular}{|c|c|c|c|c|c|}
\hline & \multirow{3}{*}{ Independent variables } & \multicolumn{4}{|c|}{ Dependent variables: performance indicators } \\
\hline & & Innovation (1) & Productivity (2) & Employment (3) & Exports (4) \\
\hline & & Ordered probit & Ordered probit & Ordered probit & Ordered probit \\
\hline \multirow{2}{*}{ Network position } & Coreness & $9.716^{*}$ & 7.099 & 1.239 & $44.550 * * *$ \\
\hline & Coreness squared & $-36.883^{*}$ & -11.38 & -5.22 & $-318.693 * *$ \\
\hline \multirow{2}{*}{$\begin{array}{l}\text { Absorptive } \\
\text { capacities }\end{array}$} & R\&D staff & $0.200 *$ & 0.111 & $0.239 * *$ & 0.027 \\
\hline & Staff qualifications & 0.096 & $0.260 * *$ & -0.024 & 0.206 \\
\hline \multirow{3}{*}{$\begin{array}{l}\text { Organizational } \\
\text { capacities }\end{array}$} & Quality management & $0.277 *$ & 0.037 & -0.099 & -0.094 \\
\hline & Quality certifications & -0.145 & -0.021 & -0.081 & $0.590 * * *$ \\
\hline & Agile methodologies & 0.115 & 0.008 & -0.041 & $0.421 * * *$ \\
\hline \multirow{4}{*}{ Business models } & Customized developments & -0.036 & 0.285 & -0.042 & 0.427 \\
\hline & Own products and services & -0.212 & 0.348 & -0.244 & $0.724 * *$ \\
\hline & Services for third-party developments & $-0.562 *$ & 0.245 & -0.226 & 0.085 \\
\hline & Outsourcing & $-0.629 *$ & 0.071 & -0.086 & 0.627 \\
\hline \multirow{6}{*}{ Control variables } & Subsidies & -0.006 & -0.028 & 0.163 & 0.337 \\
\hline & Size & -0.134 & -0.289 & $0.418 * *$ & -0.059 \\
\hline & Age & 0.006 & $-0.303 * * *$ & $0.394 * * *$ & 0.153 \\
\hline & Location & 0.041 & -0.118 & -0.1 & 0.269 \\
\hline & Constant & $* * *$ & $* * *$ & $* * *$ & $* * *$ \\
\hline & No. of observations & 189 & 189 & 189 & 189 \\
\hline
\end{tabular}

Source: prepared by the authors, on the basis of a database constructed in the framework of the project on absorption capacities and connectedness in local production and innovation systems financed by the Carolina Foundation.

Note: *significant at $10 \%$; ** significant at $5 \%$; *** significant at $1 \%$.

\section{VI}

\section{Conclusions}

This research has examined innovation processes and performance in Argentine software and IT services firms on the basis of organizational and absorptive capacities built up over their life cycle, and their position in the network architecture. We attempted to provide an evolutionary explanation for the industry's recent growth, taking into account capacity-building and the linkaging of external and internal knowledge. Differences between firms in terms of their business models show that this is a highly heterogeneous sector and that uneven capacity development has to do with the specific needs of each subsegment, and has a differentiated impact on employment, productivity and exports. 
We have incorporated into the analysis some key dimensions for understanding firms' capacities and their linkages they form with other agents and institutions to upgrade those capacities, partly in line with the proposals of Gallouj and Savona (2009). In this regard, indicators were designed for organizational and absorptive capacities that, given that this is a knowledge-intensive sector, went beyond those traditionally used in innovation surveys. In the case of organizational capacities, these included the use of agile methodologies, quality management and the application of specific quality standards. Absorptive capacities were estimated on the basis of: (i) the proportion of professionally qualified staff and the presence of postgraduate employees in the firm's total staff, and (ii) the presence and formality of R\&D staff in an indicator that captured a range of situations from the absence of even a troubleshooting team to the presence of a formal R\&D department. This is especially relevant in this industry, in which scale is not all-important, especially for business models such as customized developments.

The results of the models partly bear out the first three hypotheses. Innovation outcomes depend on quality management, R\&D staff and an intermediate network position. With regard to the fourth hypothesis, the models show that the different measures of performance in the software and IT services industry cannot be explained by a single set of indicators. The differences between firms within the industry not only in terms of capacities and connectedness, but also performance, cannot be disregarded. While the level of labour productivity can be attributed to worker qualifications, the employment dynamic correlates positively with firm size and the existence and formality of R\&D staff, while external-market participation depends on quality certification, the use of agile methodologies and an intermediate position in the network architecture.

This work highlights the theoretical and methodological difficulties involved in approaching innovation processes in knowledge-intensive software and IT services sectors, given that the estimate of innovation activity based on methodologies used in the manufacturing industry — centred on the development of new products and processes - loses explanatory power. This is particularly true for firms producing customized developments, since developing new products or processes is the very nature of the business and does not necessarily constitute an innovation. Accordingly, both the literature review and the discussion of the descriptive statistics and the model raise issues that would have to be included in a research agenda on the relations between capacities, innovation efforts and performance in an industry such as this one, which is becoming increasingly important in the region's occupational structure. Consistently with the arguments of Gallouj and Savona (2009), analysis of the results of this study point to the need to consider the specificities of the software and IT services industry and, in turn, to take into account those aspects of the innovation process in the manufacturing industry which can be assimilated into the development of the software and IT services industry (Drejer, 2004). In this context, it is particularly important to study innovation processes as interactive or systemic phenomena, in which clientsupplier linkages, network presence and the use of external knowledge sources are crucial.

This raises new questions and future lines of research surrounding the need to: (i) advance towards a conceptualization of innovation for services in general and software and IT services in particular, and (ii) determine which measures explain the success of software and IT services in the market. This would require, as well, a study of what type of technological trajectories and evolutionary paths are associated with good performance, and how feedback mechanisms arise between connectedness and technological and organizational capacities that can lead to innovation as an emerging property. This range of dimensions would require case studies in firms with very different technological, organizational, commercial and absorptive capacities, and very uneven business models and network architecture position. 
ANNEX A

TABLE A.

Relation between capacities and structural variables

(Percentages)

\begin{tabular}{|c|c|c|c|c|}
\hline & \multicolumn{4}{|c|}{ Firm size by number of workers, 2010} \\
\hline & Up to 10 & $11-50$ & 51 or more & Total \\
\hline \multicolumn{5}{|l|}{ R\&D staff: } \\
\hline - none & 50.0 & 35.0 & 15.0 & 100.0 \\
\hline - occasional informal & 44.3 & 44.2 & 11.5 & 100.0 \\
\hline - regular informal & 30.8 & 44.2 & 25.0 & 100.0 \\
\hline - formal & 7.3 & 54.5 & 38.2 & 100.0 \\
\hline Total & 30.3 & 46.3 & 23.4 & 100.0 \\
\hline \multicolumn{5}{|c|}{ Pearson chi2(6) $=27.0685$ Value $P=0.000$} \\
\hline \multicolumn{5}{|l|}{ Worker qualifications: } \\
\hline - low & 50.9 & 45.3 & 3.8 & 100.0 \\
\hline - medium & 46.8 & 44.7 & 8.5 & 100.0 \\
\hline - high & 9.5 & 50.0 & 40.5 & 100.0 \\
\hline Total & 31.0 & 47.3 & 21.7 & 100.0 \\
\hline \multicolumn{5}{|c|}{ Pearson chi2 $(4)=48.5641$ Value $P=0.000$} \\
\hline \multicolumn{5}{|l|}{ Agile methodologies: } \\
\hline - never & 40.6 & 50.0 & 9.4 & 100.0 \\
\hline - sometimes & 35.9 & 42.3 & 21.8 & 100.0 \\
\hline - always value $\mathrm{P}$ & 18.2 & 50.0 & 31.8 & 100.0 \\
\hline Total & 30.1 & 46.6 & 23.3 & 100.0 \\
\hline \multicolumn{5}{|c|}{ Pearson $\operatorname{chi} 2(4)=10.5076$ Value $P=0.033$} \\
\hline \multicolumn{5}{|l|}{ Quality management: } \\
\hline - Up to 1 effort & 45.7 & 47.8 & 6.5 & 100.0 \\
\hline - between 2 and 3 efforts & 41.2 & 45.6 & 13.2 & 100.0 \\
\hline-4 or 5 efforts & 8.6 & 45.7 & 45.7 & 100.0 \\
\hline Total & 29.9 & 46.2 & 23.9 & 100.0 \\
\hline \multicolumn{5}{|c|}{ Pearson $\operatorname{chi} 2(4)=40.3733$ Value $P=0.000$} \\
\hline \multicolumn{5}{|l|}{ Certifications: } \\
\hline - none & 47.9 & 42.2 & 9.9 & 100.0 \\
\hline - one & 23.8 & 56.3 & 20.0 & 100.0 \\
\hline - two or more & 3.1 & 33.3 & 63.6 & 100.0 \\
\hline Total & 29.3 & 46.8 & 23.9 & 100.0 \\
\hline
\end{tabular}

Pearson chi2 $(4)=48.2325$ Value $P=0.000$

Receives subsidy

\begin{tabular}{|c|c|c|c|}
\hline & No & Yes & Total \\
\hline \multicolumn{4}{|l|}{ Quality management: } \\
\hline - Up to 1 effort & 58.7 & 41.3 & 100.0 \\
\hline - between 2 and 3 efforts & 29.4 & 70.6 & 100.0 \\
\hline-4 or 5 efforts & 20.0 & 79.7 & 100.0 \\
\hline Total & 33.3 & 66.7 & 100.0 \\
\hline \multicolumn{4}{|c|}{ Pearson $\operatorname{chi} 2(2)=19.0684$ Value $\mathrm{P}=0.000$} \\
\hline \multicolumn{4}{|l|}{ Certifications: } \\
\hline - none & 47.9 & 52.1 & 100.0 \\
\hline - one & 22.5 & 77.5 & 100.0 \\
\hline - two or more & 25.0 & 75.0 & 100.0 \\
\hline Total & 32.0 & 67.2 & 100.0 \\
\hline
\end{tabular}

Pearson $\operatorname{chi} 2(2)=12.0686$ Value $\mathrm{P}=0.002$

Source: prepared by the authors on the basis of a survey conducted in the framework of a project financed by the Carolina Foundation.

Note: Pearson chi2: 6, 4 or 2 degrees of freedom.

R\&D: research and development. 
ANNEX B

Structure of firms' linkages network

On the basis of the information obtained in each firm, we built a database recording linkages geared towards improving three aspects of techno-organizational capabilities: (i) quality management, (ii) technical assistance, and (iii) joint R\&D activities. The database was processed using UCINET software. This identified the interviewed firms' linkages with clients, suppliers, competitors, business chambers, scientific and technical organizations and consultants, all in a single network.

Figure 1 shows the linkages structure of the firms interviewed. The black nodes represent firms interviewed and the white nodes represent partners who were not interviewed.

Linked firms (65\%) registered an average of 2.7 linkages per node.

FIGURE 1



Source: prepared by the authors on the basis of a survey conducted in the framework of a project financed by the Carolina Foundation. 
Arora, A. and A. Gambardella (2005), From Underdogs to Tigers: The Rise and Growth of the Software Industry in Brazil, China, India, Ireland, and Israel, New York, Oxford University Press.

Aspiazu, D., E. Basualdo and H. Nochteff (1990), "Los límites de las políticas industriales en un período de reestructuración regresiva: El caso de la informática en la Argentina”, Desarrollo Económico, vol. 30, No. 118, Buenos Aires, Institute of Economic and Social Development.

(1986), "Estructuras y transformaciones de la industria electrónica en Argentina", Documentos e Informes de Investigación series, No. 45, Buenos Aires, Latin American Faculty of Social Sciences (FLACSO).

Babini, R. (2003), La Argentina y la computadora: Crónica de una frustración, Buenos Aires, Ed. Dunken.

Barabási, A. and R. Albert (1999), "Emergence of scaling in random networks", Science, vol. 286, No. 5439, New York, American Association for the Development of Science.

Borgatti, S.P., M.G. Everett and L.C. Freeman (2002), Ucinet for Windows: Software for Social Network Analysis, Harvard, Massachusetts, Analytic Technologies.

Boschma, R. and A. ter Wal (2006), "Knowledge networks and innovative performance in an industrial district: the case of a footwear district in the South of Italy", Papers in Evolutionary Economic Geography, No. 601, Utrecht, University of Utrecht.

Boschma, R. and A. Weterings (2005), "The effect of regional differences on the performance of software firms in the Netherlands", Journal of Economic Geography, vol. 5, No. 5, Oxford, Oxford University Press.

CESSI (Chamber of Business for Software and Information Services of Argentina) (2012), "Reporte semestral sobre el sector de software y servicios informáticos de la República Argentina. Primer semestre 2011" [online] http://www.cessi.org.ar/documentacion/ OPPSI_ReporteSemestralSectorSoftware_31_06_11.pdf.

Chudnovsky, D., A. López and S. Melitsko (2001), "El sector de software y servicios informáticos en la Argentina. Situación actual y perspectivas de desarrollo", Documento de Trabajo, No. 27, Buenos Aires, Research Centre for Industrial Transformation.

Cohen, W. and D. Levinthal (1990), "Absorptive capacity: a new perspective on learning and innovation", Administrative Science Quarterly, vol. 35, No. 1, Ithaca, University of Cornell.

Coombs, R. and I. Miles (2000), "Innovation, measurement and services: the new problematique", Economics of Science, Technology and Innovation, vol. 18, Springer.

Corrocher, N., L. Cusmano and A. Morrison (2009), "Modes of innovation in knowledge-intensive business services evidence from Lombardy", Journal of Evolutionary Economics, vol. 19, No. 2, Springer.

Cowan, R. and N. Jonard (2004), "Network structure and the diffusion of knowledge", Journal of Economic Dynamics and Control, vol. 28, No. 8, June, Amsterdam, Elsevier.

(2003), "The dynamics of collective invention", Journal of Economic Behavior \& Organization, vol. 52, No. 4.

Cusumano, Michael A. (2012), "Platforms versus products: observations from the literature and history", Advances in Strategic Management, vol. 29, Emerald Group Publishing. (2010), "Cloud computing and SaaS as new computing platforms", Communications of the ACM, vol. 53, No. 4, April.

Cusumano, M.A. and D.B. Yoffie (1999), "Software development on Internet time", Computer, vol. 32, No. 10, IEEE Computer Society.

CUTI (Uruguayan Chamber of Information Technology) (2012) [online] www.cuti.org.uy.

De Bresson, C. and F. Amesse (1991), "Networks of innovators: a review and introduction to the issue", Research Policy, No. 20, Amsterdam, Elsevier.
Djellal, F. and F. Gallouj (2001), "Patterns of innovation organisation in service firms: portal survey results and theoretical models", Science and Public Policy, vol. 28, No. 1, Oxford University Press. (1999), "Services and the search for relevant innovation indicators: a review of national and international surveys", Science and Public Policy, vol. 26, No. 4, Oxford University Press.

Dosi, G. (2000), Innovation, Organization and Economic Dynamics: Selected Essays, Cheltenham, Edward Elgar Publishing.

Drejer, I. (2004), "Identifying innovation in surveys of services: a Schumpeterian perspective". Research Policy, vol. 33, No. 3, Amsterdam, Elsevier.

Freeman, C. (1991), "Networks of innovators: a synthesis of research issues", Research Policy, vol. 20, No. 5, Amsterdam, Elsevier.

Gallouj, F. and M. Savona (2009), "Innovation in services: a review of the debate and a research agenda", Journal of Evolutionary Economics, vol. 19, No. 2, Springer.

Gallouj, F. and O. Weinstein (1997), "Innovation in services", Research Policy, vol. 26, No. 4-5, Amsterdam, Elsevier.

Giuliani, E. and M. Bell (2005), "The micro-determinants of mesolevel learning and innovation: evidence from a Chilean wine cluster", Research Policy, vol. 34, No. 1, Amsterdam, Elsevier.

Grimaldi, R. and S. Torrisi (2001), "Codified-tacit and generalspecific knowledge in the division of labour among firms: a study of the software industry", Research Policy, vol. 30, No. 9, Amsterdam, Elsevier.

Gulati, R. (1999), "Where do interorganizational networks come from?", American Journal of Sociology, vol. 104, No. 5, Chicago, University of Chicago Press.

Hargadon, A. (2003), How Breakthroughs Happen: The Surprising Truth About How Companies Innovate, Harvard Business Press.

Hughes, A. and E. Wood (2000), "Rethinking innovation comparisons between manufacturing and services: the experience of the CBR SME Surveys in the UK", Innovation Systems in the Service Economy. Measurement and Case Study Analysis, J.S. Metcalfe and I.D. Miles, Boston, Kluwer Academic Publishers.

INDEC (National Institute of Statistics and Censuses) (2005), Encuesta Nacional de Innovación Tecnologica, Buenos Aires.

Klepper, S. and K.L Simons (2000), "Dominance by birthright: entry of prior radio producers and competitive and competitive ramifications in the U.S. television receiver industry", Strategic Managment Journal, vol. 21, No. 10-11, John Wiley \& Sons.

Landau, R. and N. Rosenberg (1986), The Positive Sum Strategy. Harnessing Technology for Economic Growth, Washington, D.C., National Academy Press.

López, A. and D. Ramos (2007), "La industria de software en el MERCOSUR", Complementación productiva en la industria del software en los países del MERCOSUR: Impulsando la integración regional para participar en el mercado global, A. López (coord.), Documento de trabajo, No. 1-07, Buenos Aires, cENIT.

Nelson, R. and S. Winter (1982), An Evolutionary Theory of Economic Change, Cambridge, Massachusetts, Harvard University Press.

OECD (Organisation for Economic Cooperation and Development) (2002), OECD Information Technology Outlook. ICTs and the Information Economy, Paris.

OEDE/MTss (Employment and Business Dynamics Observatory/Ministry of Labour and Social Security) (2012) [online] http://www. trabajo.gov.ar/left/estadisticas/oede/index.asp.

Parthasarathy, B. and Y. Aoyama (2006), "From software services to R\&D services: local entrepreneurship in the software industry in Bangalore, India", Environment and Planning A, vol. 38, No. 7.

Powell, W.W., K. Koput and L. Smith-Doerr (1996), "Interorganizational collaboration and the locus of innovation: networks of learning in biotechnology", Administrative Science Quarterly, vol. 41, No. 1, Sage Publications. 
RAIS (Annual Report of Social Information) (2012), Ministry of Labour and Employment [online] http://www.mte.gov.br/ rais/default.asp.

Romijn, H. and M. Albaladejo (2002), "Determinants of innovation capability in small electronics and software firms in southeast England", Research Policy, vol. 31, No. 7, Amsterdam, Elsevier.

Saviotti, P.P. and J.S. Metcalfe (1984), "A theoretical approach to the construction of technological output indicators", Research Policy, vol. 13, No. 3, Amsterdam, Elsevier.

Savona, M. (2004), "Structural change and macro-economic performance. The structural bonus hypothesis for services", paper presented at the XIV International Conference of RESER (Castres and Toulouse, France, 23-25 September).

Schilling, M.A. and C. Phelps (2004), "Interfirm collaboration networks: the impact of network structure on rates of innovation", Working Paper, New York, Stern School of Business.

Segelod, E. and G. Jordan (2002), "The use and importance of external sources of knowledge in the software development process", FE rapport, No. 2002-391, Göteborg, Sweden, University of Göteborg.

Silverberg, G., G. Dosi and L. Orsenigo (1988), "Innovation, diversity and diffusion: a self-organisation model", The Economic Journal, vol. 98, No. 393, Royal Economic Society.
Sirilli, G. and R. Evangelista (1998), "Technological innovation in services and manufacturing: results from Italian surveys", Research Policy, vol. 27, No. 9, Amsterdam, Elsevier.

SOFTEX (2012), "Software e serviços de TI: A indústria brasileira em perspectiva", vol. 2 [online] publicacao.observatorio.softex.br/.

Verspagen, B. and G. Duysters (2004), "The small worlds of strategic technology alliances", Technovation, vol. 24, No. 7, Amsterdam, Elsevier.

Watts, D. (2006), Seis grados de separación: La ciencia de las redes en la era del acceso. Editorial Paidós. (1999), "Networks, dynamics, and the small-world phenomenon", American Journal of Sociology, vol. 105.

Yoguel, G. and others (2004), "Information and knowledge: the diffusion of information and communication Technologies in the Argentine manufacturing sector", CEPAL Review, No. 82 (LC/G.2220-P), Santiago, Chile, April.

Yoguel, G. and V. Robert (2010), "Capacities, processes and feedbacks: the complex dynamics of development", Seoul Journal of Economics, vol. 23, No. 2.

Zuckerfeld, M. and others (2012), "Una aproximación al subsector del software y servicios informáticos (SSI) y las políticas públicas en la Argentina", presentation at the tenth Symposium of the Information Society. 